\title{
Effect of Nonenzymatic Antioxidants on Sperm Motility and Survival Relative to Free Radicals and Antioxidant Enzymes of Chilled-Stored Ram Semen
}

\author{
Moustafa M. Zeitoun ${ }^{1 *}$, Mona A. Al-Damegh ${ }^{2}$ \\ ${ }^{1}$ Department of Animal Production and Breeding, College of Agriculture and Veterinary Medicine, Qassim \\ University, Buriedah, KSA \\ ${ }^{2}$ Department of Biology, College of Sciences and Arts, Qassim University, Oniza, KSA \\ Email: mmzeitoun@yahoo.com
}

Received 8 December 2014; accepted 29 December 2014; published 13 January 2015

Copyright (C) 2015 by authors and Scientific Research Publishing Inc.

This work is licensed under the Creative Commons Attribution International License (CC BY).

http://creativecommons.org/licenses/by/4.0/

(c) (;) Open Access

\section{Abstract}

The effect of inclusion of three antioxidants (Vitamin E, cysteine and glutathione) in ram semen extender on the release of antioxidant enzymes and free radicals was studied. A $3 \times \mathbf{3}$ factorial experiment was conducted to test effects of supplementing ram semen extender with Vitamin E (1, 5 and $10 \mathrm{IU})$, cysteine $(1,5$ and $10 \mathrm{mM})$ or glutathione $(0.5,1$ and $2 \mathrm{mM})$ on the sperm survival and release of superoxide dismutase (SOD), glutathione peroxidase (GPX) and thiobarbituric acid reactive substances (TBARS). Eighty ejaculates of eight fertile Najdi rams were collected, assessed for the gross examination and the good ejaculates ( $\geq 90 \%$ motility) were pooled and sperm count was assessed. Therefore ten extenders; control (C) and 9 treated (C plus antioxidant) were tested. Extended semen was stored at $5^{\circ} \mathrm{C}$ for $96 \mathrm{~h}$, examined for motility and survival and sperm cells were separated from plasma, sonicated, homogenized and exposed to the determinations of SOD, GPX and TBARS. The highest sperm survival was found in diluents containing 5 IU Vitamin E/ml, 1 and $2 \mathrm{mM}$ glutathione (55.5\% survival), while the lowest survival was found in $10 \mathrm{mM}$ cysteine $(11.1 \%)$. TBARS concentration was highest $(P<0.05)$ in control than other treatments, however, Vitamin $E$ and glutathione exhibited low values. Contrariwise, activities of SOD and GPX increased $(P<0.05)$ within sperm cells and seminal plasma in diluents containing $5 \mathrm{IU}$ E, $1 \mathrm{mM}$ and $2 \mathrm{mM}$ glutathione. The enzymatic activities were generally higher in seminal plasma than in sperm cells. It was concluded that supplementing ram semen extender during chilled storage with 5 IU Vitamin E per $\mathrm{ml}$ or 1 - $2 \mathrm{mM}$ glutathione enhanced sperm survival and reduced free radicals.

\footnotetext{
"Corresponding author.
} 


\section{Keywords}

\section{Ram, Semen Storage, Free Radicals, Antioxidant Enzymes}

\section{Introduction}

Semen contains various unsaturated fatty acids which are oxidized during preservation resulting in reactive oxygen species (ROS). These oxygen species are very active on the cellular level resulting in various degrees of damage to the sperm cells. Sperm cells are very susceptible to lipid peroxidation by free radicals such as hydrogen peroxide, superoxide anion, and hydroxyl radical which could later lead to the structural damage of sperm membranes during the aerobic storage of sperm [1]. Cold shock during semen preservation poses stress on the sperm cell membrane via the free radicals leading to sperm damage [2] [3]. The mechanism by which the free radicals do their damage was ascribed to their ability to catch the electrons from the nucleic acids, lipids and proteins causing the cell damage [4]. Much work has been done to protect the integrity of the sperm cells of different species from physical and chemical damage during processing and preservation. Enzymatic and non enzymatic antioxidants have been tested on this aspect. The ROS can be neutralized by an antioxidant system, comprised of reduced glutathione (GSH), GPX, catalase (CAT) and SOD. Added to that the various non-enzymatic molecules such as glutathione, thioredoxin and other thiol-containing molecules, as well as Vitamins D, E and $\mathrm{C}$ which serve as a defense mechanism against the lipid peroxidation of semen and maintaining sperm motility and viability. Vitamin E ( $\alpha$-tocopherol) was found to owe the ability to maintain a steady-state rate of peroxyl radical reduction in the plasma membrane depending on the recycling of $\alpha$-tocopherol by external reducing agents such as ascorbate or thiols [5] [6].

Glutathione is a tripeptide naturally occurring in semen and providing intracellular defense to the sperm against the oxidative stress caused by an over-production of ROS during the freezing and thawing process. Glutathione supplementation in semen extender up to a level of $2 \mathrm{mM}$ was found to be protective against the damaging effects of free radicals, beyond that no protective effects were found in bull spermatozoa [7]. The addition of glutathione to the semen extender prevented the loss of sperm motility by inhibition of lipid peroxidation caused by ROS in frozen thawed bull semen [7] and goats [1]. Moreover, glutathione increased the viability, plasma membrane and acrosomal integrity after thawing buffalo spermatozoa [8].

This antioxidant alters the available free radicals to molecules that have less negative impacts on the cell. Its addition to semen diluents is expected to decrease or prevent the emergence of free radicals that can ruin the plasma membranes [9]. Other compounds containing sulfhydryl groups as cysteine and ergothionein play an important role in maintaining metabolic functions and cell motility of sperm [10]. It has also been shown that addition of L-cysteine up to $2.0 \mathrm{mM}$ in Tris-citric acid extender improved the post-thaw quality of Sahiwal bull semen [11]. Therefore, it was the objective of the current study to evaluate effects of supplementing Najdi ram semen extender with Vitamin E, cysteine or glutathione at various concentrations on sperm motility and survival and on the releases of free radicals and antioxidant enzymes within sperm cells and seminal plasma.

\section{Materials and Methods}

\subsection{Animals and Semen Collection}

Eight healthy mature Najdi rams ( 2 - 3 years of age) were used in this study. The rams were fed on a traditional diet of barley (1 kg/head/day) and alfalfa hay, housed in semi-shaded yards and offered clean drinking water and integrated salt licks as free choice. The study was carried out at Qassim University Experimental Station from September 2013 to January 2014.

Semen was collected twice a week for five consecutive weeks. A total number of 80 ejaculates were collected from the rams using an artificial vagina (10 ejaculates/ram). At semen collection, rams were exposed to estrous ewes and semen was collected after teasing the ram for two times false mounts. Ejaculates were evaluated and included in the study if the following criteria were met: volume of $0.5-2 \mathrm{ml}$ and the progressive motile sperms percentage was equal to or higher than $90 \%$. Semen ejaculates of good quality were pooled to avoid the ram effect and equally distributed into 10 diluents. 


\subsection{Semen Processing and Dilution}

\subsubsection{Basic Semen Extender}

The basic extender (control) comprised of $3.63 \mathrm{~g}$ Tris (hydroxy methyl aminometahne), $0.50 \mathrm{~g}$ fructose, $1.99 \mathrm{~g}$ citric acid (monohydrate), $5 \mathrm{ml}$ egg yolk, $1 \mathrm{ml}$ antibiotics solution containing 100,000 IU penicillin and 100,000 $\mu \mathrm{g}$ streptomycin and glass-distilled water up to $100 \mathrm{ml}$ and $\mathrm{pH}$ was adjusted to 6.8 - 7 .

\subsubsection{Antioxidants-Containing Extenders}

The three antioxidants (Vitamin E, cysteine and glutathione) were formulated to be tested at three different levels as follow:

1) Vitamin $E$ at 1,5 and $10 \mathrm{IU} / \mathrm{ml}$;

2) Cysteine at 1,5 and $10 \mathrm{mM}$;

3) Glutathione at 0.5, 1 and $2 \mathrm{mM}$.

Therefore, control and 9 antioxidant-containing extenders were prepared for semen dilution. Treatment groups (G) were; G1 (Control, basic diluents), G2 (basic diluents containing 1 IU vitamin E/ml), G3 (basic diluents containing 5 IU vitamin E/ml), G4 (basic diluents containing 10 IU vitamin E/ml), G5 (basic diluents containing $1 \mathrm{mM}$ Cysteine), G6 (basic diluents containing $5 \mathrm{mM}$ Cysteine), G7 (basic diluents containing $10 \mathrm{mM}$ Cysteine), G8 (basic diluents containing $0.5 \mathrm{mM}$ Glutathione), G9 (basic diluents containing $1 \mathrm{mM}$ Glutathione) and G10 (basic diluents containing $2 \mathrm{mM}$ Glutathione).

\subsection{Semen Dilution, Preservation and Evaluation}

Good quality semen ejaculates were pooled and progressive motility and sperm count were assessed. The pooled sample was divided into 10 aliquots to avoid the ram effect. One volume of raw semen was added to 5 equal volumes of the designed extender. Extended semen samples $\left(37^{\circ} \mathrm{C}\right)$ surrounded by warm water jacket $\left(37^{\circ} \mathrm{C}\right)$ were gradually cooled to $5^{\circ} \mathrm{C}$ in the refrigerator and stored for 96 hours. A semen sample was taken out after 96 $\mathrm{h}$ of storage, then warmed to $37^{\circ} \mathrm{C}$ and checked for progressive motility, viability and abnormality.

\subsection{Semen Evaluation}

Sperm motility was examined by a phase contrast microscope. To evaluate this parameter, one drop of semen was placed on a warm $\left(37^{\circ} \mathrm{C}\right)$ stage and spermatozoa with progressive motility counted used X20 objective lens. Sperm viability was assessed by Eosin Y. (0.5\%)—Nigrosin (0.1\%) staining mixture. Dead cells were stained by the Eosin, whereas the live cells retained their cellular membrane integrity preventing the stain to enter cells. Nigrosin served as a background stain to provide contrast for the unstained (white) live cells. A total of 200 sperm were assessed under oil immersion with a high-resolution (X100) objective equipped with correct adjustment of the bright field optics. Unstained spermatozoa which appeared white were classified as "live" and those that show any pink or red color were classified as "dead" [12]. Sperm survival after $96 \mathrm{~h}$ storage was estimated by dividing the percentage of progressive motility at $96 \mathrm{~h}$ by the percentage of initial progressive motility.

\subsection{Sperm Cells Sonication}

At the $96 \mathrm{~h}$ storage, extended semen was centrifuged ( 3000 rpm $\left./ 15 \mathrm{~min} / 5^{\circ} \mathrm{C}\right)$. Diluted seminal plasma was aspirated and transferred to a labeled tube and pellet of the sperm cells was resuspended in normal saline solution at a dilution rate resulting in a concentration of $1 \times 10^{9} \mathrm{sperm} / \mathrm{ml}$. Sperm cells were exposed to 2 cycles of sonication (Q-Sonic7, USA) at $1350 \mathrm{rpm}$ for 49 sec each [13]. Seminal plasma and sperm cellular contents were used later in the determination of free radicals and antioxidant enzymes.

\subsection{Superoxide Dismutase (SOD) Activity Determination}

The method of Marklund et al. was adopted to determine SOD activity by the commercial kit (SOD Assay kit, Cayman Chemical Co., Ann Arbor, MI, USA) [14]. This method utilizes tetrazolium salt for detection of superoxide radicals generated by xanthine oxidase and hypoxanthine. One unit of SOD is defined as the amount of enzyme needed to exhibit 50\% dismutation of the superoxide radicals. In this assay, total SOD was measured. Briefly, the assay procedure was done by pipetting $200 \mu \mathrm{l}$ of the diluted radical detector and $10 \mu \mathrm{l}$ standard or 
samples into each well. The reaction was initiated by adding $20 \mu \mathrm{l}$ of diluted xanthine oxidase to all wells except in background wells, $20 \mu \mathrm{l}$ sample buffer replaced xanthine oxidase. The plate was covered and gently shaken for a few seconds to thoroughly mix the samples and incubated on a shaker for 20 minutes at room temperature. Absorbance was read at $450 \mathrm{~nm}$ using a plate reader (Mindray, China). Activity of SOD in samples was derived from the standard curve using the equation obtained from the linear regression of the standard curve substituting the linear rate (LR) for each sample. Enzyme activity $(\mathrm{U} / \mathrm{ml})$ was attributed to each milliliter of seminal plasma and to each $1 \times 10^{9}$ sperm in the sperm suspension.

\subsection{Glutathione Peroxidase (GPX) Activity Measurement}

According to Paglia and Valentine [15], the GPX activity was assessed by using a commercial kit (Cayman Chemical Co., Ann Arbor, MI, USA). The procedure depends on measurement of GPX activity indirectly by a coupled reaction with glutathione reductase (GR). Oxidized glutathione (GSSG) produced upon reduction of hydroperoxide by GPX, and is recycled to its reduced state by GR and NADPH. The oxidation of NADPH to $\mathrm{NADP}^{+}$is accompanied by a decrease in the absorbance at $340 \mathrm{~nm}$. Under a condition in which the GPX activity is rate limiting, the rate of decrease in the absorbance is directly proportional to the GPX activity in the sample. The GPX activity in seminal plasma was expressed as $\mathrm{nmol} / \mathrm{min} / \mathrm{ml}$, and in sperm cells as $\mathrm{nmol} / \mathrm{min} / 10^{9}$ spermatozoa.

\subsection{Lipid Peroxidation (LPO) Measurement}

The LPO levels in seminal plasma and sperm suspension were determined according to Armstrong and Browne [16] using a commercial kit (TBARS Assay kit, Cayman Chemical Co., Ann Arbor, MI, USA). The method was performed on the basis of the reaction of the thiobarbituric acid (TBA) with malondialdehyde (MDA) under high temperature $\left(90^{\circ} \mathrm{C}-100^{\circ} \mathrm{C}\right)$, then the resultant color was measured at $540 \mathrm{~nm}$. The sample concentration of TBARS was calculated from the standard curve and expressed as $\mu \mathrm{M} \mathrm{MDA} / \mathrm{ml}$ seminal plasma or $\mu \mathrm{M} \mathrm{MDA} / 10^{9}$ spermatozoa.

\subsection{Statistical Analysis}

Data of sperm motility and survival were analyzed by the least square analysis of variances (ANOVA, SAS 2000) [17]. Data of TBARS and enzymatic activities were subjected to one-way analysis of variances. Differences between treatments were compared by the Duncan Multiple Range Test (DMRT) [18]. Significant level was considered at $\mathrm{P}<0.05$.

\section{Results}

\subsection{Semen Characteristics}

The highest post-thaw motility and sperm survival (50\% and 55.5\%) $96 \mathrm{~h}$ after storage at $5^{\circ} \mathrm{C}$ (Table 1) were attained in the basal diluents containing 5 IU Vitamin E, $1 \mathrm{mM}$ and $2 \mathrm{mM}$ glutathione. Likewise, the correspondent percentages of live spermatozoa were $65 \%, 65 \%$ and $68 \%$, respectively. Contrariwise, percentages of sperm abnormalities for the three previous treatments were $20 \%, 15 \%$ and $15 \%$, respectively. The lowest $(\mathrm{P}<$ 0.05) survival (11.1\%, Table 1) was found in the basal diluents containing $10 \mathrm{mM}$ cysteine followed by $5 \mathrm{mM}$ cysteine. The only improvement on sperm survival that cysteine has done over the control (22.2\%) was found at $1 \mathrm{mM}$ concentration (33.3\%). Inclusion of Vitamin E up to $5 \mathrm{IU} / \mathrm{ml}$ in the diluents improved the viability and survival of ram sperm. Beyond 5 IU Vitamin E, there appears to exert adverse effects on sperm viability and survival (Table 1).

\subsection{Free Radicals}

Free radicals concentrations (Table 2) considerably decreased $(\mathrm{P}<0.05)$ in all treatments compared with control. The least TBARS concentrations were found in diluents contained 1 and 5 IU Vitamin E and in all glutathione containing-diluents. Cysteine-containing diluents resulted in intermediate levels of TBARS. There found significant $(\mathrm{P}<0.05)$ low levels of TBARS in ram sperm cells than in seminal plasma (Table 2$)$ in all treatments. The magnitude of the TBARS concentration in control seminal plasma was 2.9 folds that found in sperm cells. 
Table 1. Effect of type and concentration of antioxidant in ram semen extender on percentage of sperm progressive motility, abnormality, livability and survival rate after $96 \mathrm{~h}$ storage at $5^{\circ} \mathrm{C}(\mathrm{LSM} \pm \mathrm{SEM})^{* *}$.

\begin{tabular}{|c|c|c|c|c|c|}
\hline Antioxidant-Extender & $\%$ Initial Motility & $\begin{array}{l}\text { \% Progressive Motility } \\
\text { after } 96 \mathrm{~h}\left(5^{\circ} \mathrm{C}\right)\end{array}$ & $\begin{array}{c}\text { \% Live Sperm after } \\
96 \mathrm{~h}\left(5^{\circ} \mathrm{C}\right)\end{array}$ & $\begin{array}{l}\% \text { Abnormality } \\
\text { after } 96 \mathrm{~h}\left(5^{\circ} \mathrm{C}\right)\end{array}$ & $\%$ Sperm Survival \\
\hline Control $(\mathrm{C})^{*}$ & 90 & $20^{\mathrm{a}} \pm 5.0^{* *}$ & $30^{\mathrm{a}} \pm 4.0$ & $40^{\mathrm{a}} \pm 3.0$ & 22.2 \\
\hline $\mathrm{C}+1 \mathrm{IU} \mathrm{E} / \mathrm{ml}$ & 90 & $40^{\mathrm{b}} \pm 4.0$ & $50^{\mathrm{b}} \pm 5.0$ & $30^{\mathrm{b}} \pm 3.0$ & 44.4 \\
\hline $\mathrm{C}+5 \mathrm{IU} \mathrm{E} / \mathrm{ml}$ & 90 & $50^{\mathrm{b}} \pm 5.0$ & $65^{\mathrm{c}} \pm 5.0$ & $20^{\mathrm{c}} \pm 5.0$ & 55.5 \\
\hline $\mathrm{C}+10 \mathrm{IU} \mathrm{E} / \mathrm{ml}$ & 90 & $30^{c} \pm 2.0$ & $40^{\mathrm{a}} \pm 5.0$ & $25^{\mathrm{b}} \pm 3.0$ & 33.3 \\
\hline C + 1 mM Cyst. & 90 & $30^{\mathrm{c}} \pm 3.0$ & $35^{\mathrm{a}} \pm 4.0$ & $30^{\mathrm{b}} \pm 4.0$ & 33.3 \\
\hline C + 5 mM Cyst. & 90 & $20^{\mathrm{a}} \pm 3.0$ & $30^{\mathrm{a}} \pm 3.0$ & $30^{\mathrm{b}} \pm 5.0$ & 22.2 \\
\hline C + 10 mM Cyst. & 90 & $10^{\mathrm{d}} \pm 2.0$ & $15^{\mathrm{d}} \pm 3.0$ & $40^{\mathrm{a}} \pm 5.0$ & 11.1 \\
\hline C + 0.5 mM Glut. & 90 & $40^{\mathrm{b}} \pm 5.0$ & $50^{\mathrm{b}} \pm 3.0$ & $20^{\mathrm{c}} \pm 5.0$ & 44.4 \\
\hline $\mathrm{C}+1 \mathrm{mM}$ Glut. & 90 & $50^{\mathrm{b}} \pm 5.0$ & $65^{\mathrm{c}} \pm 5.0$ & $15^{\mathrm{c}} \pm 2.0$ & 55.5 \\
\hline $\mathrm{C}+2$ mM Glut. & 90 & $50^{\mathrm{b}} \pm 4.0$ & $68^{\mathrm{c}} \pm 5.0$ & $15^{\mathrm{c}} \pm 2.0$ & 55.5 \\
\hline
\end{tabular}

${ }^{*}$ Control extender: Tris-Citric-Fructose-Egg Yolk; E = Vitamin E; Cyst. = Cysteine; Glut. = Glutathione. ${ }^{* *}$ Means in the same column with different superscripts significantly differ $(\mathrm{P}<0.05)$.

Table 2. Effect of type and concentration of antioxidant in ram semen extender on the free radicals concentration and antioxidant enzyme activity after $96 \mathrm{~h}$ storage at $5^{\circ} \mathrm{C}(\mathrm{LSM} \pm \mathrm{SEM})^{* *}$.

\begin{tabular}{|c|c|c|c|c|c|c|}
\hline \multirow{2}{*}{ Antioxidant-Extender } & \multicolumn{2}{|c|}{ TBARS ( $\mu$ MMDA) } & \multicolumn{2}{|c|}{ SOD (U) } & \multicolumn{2}{|c|}{ GPX (nmol/min) } \\
\hline & Sperm $\left(/ 10^{9}\right)$ & Plasma (/ml) & Sperm $\left(/ 10^{9}\right)$ & Plasma (/ml) & Sperm $\left(/ 10^{9}\right)$ & Plasma (/ml) \\
\hline Control $(\mathrm{C})^{*}$ & $15.13^{\mathrm{a}} \pm 0.45$ & $43.68^{\mathrm{a}} \pm 3.5$ & $15.9^{\mathrm{a}} \pm 3.7$ & $32.8^{\mathrm{a}} \pm 5.6$ & $12.5^{\mathrm{a}} \pm 2.6$ & $22.1^{\mathrm{a}} \pm 3.2$ \\
\hline $\mathrm{C}+1 \mathrm{IU} \mathrm{E} / \mathrm{ml}$ & $0.12^{\mathrm{b}} \pm 0.06$ & $22.86^{\mathrm{b}} \pm 3.9$ & $25.8^{\mathrm{a}} \pm 6.7$ & $43.5^{\mathrm{a}} \pm 7.8$ & $15.6^{\mathrm{a}} \pm 2.2$ & $35.4^{\mathrm{b}} \pm 5.3$ \\
\hline $\mathrm{C}+5 \mathrm{IU} \mathrm{E} / \mathrm{ml}$ & $0.12^{\mathrm{b}} \pm 0.03$ & $18.78^{\mathrm{b}} \pm 4.5$ & $47.6^{\mathrm{b}} \pm 4.5$ & $89.5^{\mathrm{b}} \pm 4.6$ & $96.8^{\mathrm{b}} \pm 6.5$ & $137.9^{\mathrm{c}} \pm 7.4$ \\
\hline $\mathrm{C}+10 \mathrm{IU} \mathrm{E} / \mathrm{ml}$ & $2.13^{c} \pm 0.19$ & $28.01^{\mathrm{c}} \pm 6.1$ & $20.7^{\mathrm{a}} \pm 5.1$ & $29.8^{\mathrm{a}} \pm 6.7$ & $20.8^{\mathrm{a}} \pm 8.5$ & $30.4^{\mathrm{b}} \pm 5.5$ \\
\hline C + 1 mM Cyst. & $1.14^{\mathrm{c}} \pm 0.13$ & $12.78^{\mathrm{b}} \pm 2.6$ & $22.6^{\mathrm{a}} \pm 6.1$ & $36.1^{\mathrm{a}} \pm 3.9$ & $17.9^{\mathrm{a}} \pm 7.6$ & $26.8^{\mathrm{b}} \pm 5.1$ \\
\hline C + 5 mM Cyst. & $0.94^{\mathrm{bc}} \pm 0.22$ & $17.28^{\mathrm{b}} \pm 3.1$ & $16.7^{\mathrm{a}} \pm 3.2$ & $34.4^{\mathrm{a}} \pm 5.3$ & $14.5^{\mathrm{a}} \pm 6.6$ & $22.6^{\mathrm{a}} \pm 2.3$ \\
\hline C + 10 mM Cyst. & $2.59^{\mathrm{c}} \pm 0.31$ & $31.58^{\mathrm{c}} \pm 3.8$ & $15.7^{\mathrm{a}} \pm 4.9$ & $38.6^{\mathrm{a}} \pm 4.5$ & $13.8^{\mathrm{a}} \pm 8.1$ & $27.9^{b} \pm 6.8$ \\
\hline $\mathrm{C}+0.5 \mathrm{mM}$ Glut. & $0.13^{\mathrm{b}} \pm 0.04$ & $10.17^{\mathrm{b}} \pm 4.9$ & $31.1^{\mathrm{c}} \pm 3.9$ & $45.6^{\mathrm{a}} \pm 3.6$ & $20.7^{\mathrm{a}} \pm 7.7$ & $40.2^{\mathrm{b}} \pm 2.9$ \\
\hline C + 1 mM Glut. & $0.37^{\mathrm{b}} \pm 0.09$ & $9.12^{\mathrm{b}} \pm 2.1$ & $57.4^{\mathrm{b}} \pm 6.5$ & $101.8^{\mathrm{c}} \pm 9.1$ & $89.9^{\mathrm{b}} \pm 4.5$ & $143.6^{c} \pm 5.1$ \\
\hline $\mathrm{C}+2 \mathrm{mM}$ Glut. & $0.18^{\mathrm{b}} \pm 0.12$ & $0.26^{\mathrm{d}} \pm 0.1$ & $66.7^{\mathrm{b}} \pm 3.5$ & $120.5^{c} \pm 9.2$ & $130.4^{\mathrm{c}} \pm 3.5$ & $156.9^{c} \pm 6.5$ \\
\hline
\end{tabular}

${ }^{*}$ Control extender: Tris-Citric-Fructose-Egg Yolk; E = Vitamin E; Cyst. = Cysteine; Glut. = Glutathione. ${ }^{* *}$ Means in the same column with different superscripts significantly differ $(\mathrm{P}<0.05)$.

However, this magnitude approached about 19 folds in treated samples.

\subsection{Antioxidant Enzymes}

Superoxide dismutase (SOD) activity was only significantly higher $(\mathrm{P}<0.05)$ in antioxidant-supplemented diluents with 5 IU Vitamin E/ml and 1 and $2 \mathrm{mM}$ glutathione compared with control (Table 2). The highest SOD activity either in seminal plasma $(120.5 \pm 9.2 \mathrm{U} / \mathrm{ml})$ or in sperm cells $\left(66.7 \pm 3.5 \mathrm{U} / 10^{9}\right.$ sperm) was obtained in diluents containing $2 \mathrm{mM}$ glutathione with no difference than in $1 \mathrm{mM}$ glutathione. The second high level of SOD (89.5 $\pm 4.6 \mathrm{U} / \mathrm{ml}$ plasma and $47.6 \pm 4.5 \mathrm{U} / 10^{9}$ sperm) was observed in the 5 IU Vitamin E-diluent. Cysteine at all tested levels and Vitamin E at 10 IU didn't enhance the SOD activity than the control diluents. 
Similar trend to what was found in SOD activity was obtained with GPX activity (Table 2). Also, the best GPX activity was found in the diluents contained 5 IU Vitamin E, 1 and $2 \mathrm{mM}$ glutathione. Cysteine at all molarities didn't enhance this enzyme activity over the control.

\section{Discussion}

Due to the high speed of the sperm, depending on the generation of energy by the mid-piece mitochondrial oxidative phosphorylation, a high concentration of free radicals are produced inside and outside the sperm cells [19] [20]. The increase of the production of ROS might damage the sperm cell membrane resulting in lower sperm motility and survival after storage at low temperatures [21] which leads to diminishing the sperm penetration of the cervical mucus in vitro [22]. Addition of either enzymatic or non-enzymatic specific antioxidants would impact a beneficial reduction to the free radicals. In the current study, three non-enzymatic antioxidants were chosen to be tested at 3 levels each. Vitamin E ( $\alpha$-tocopherol) and Vitamin C (ascorbic acid) were traditionally used for a long time as antioxidants. Vitamins $\mathrm{E}$ and $\mathrm{C}$ were considered as electron trapping molecules.

Vitamin $\mathrm{E}$ is considered to be the main component of the antioxidant system of spermatozoa, one of the major protectors of the membranes against ROS and lipid peroxidation attack [23]. Because of its solubility in lipids, vitamin $\mathrm{E}$ might serve as the first line of defense against the peroxidation of the polyunsaturated fatty acids on the membranous phospholipids structure [24] [25]. The present study concluded that vitamin E concentration in ram semen extender must not exceed $5 \mathrm{IU} / \mathrm{ml}$ to achieve the best post-thaw motility and survival with the highest antioxidant enzyme activity. At a similar level, Anghel et al. found better post-thaw sperm parameters of frozen ram semen [26]. Also, Michael et al. found protective effects of low level of Vitamin E (0.3 mM) on frozen dog sperm [27]. Also, the concentration of Vitamin E up to $1.0 \mathrm{mM}$ offer protection against membrane oxidative stress of frozen ram sperm [28].

Natural compounds containing thiol group are considered precursors of intracellular reduced glutathione biosynthesis. Addition of cysteine to the semen extender prevents loss of sperm motility by inhibition of lipid peroxidation caused by ROS in frozen-thawed bull semen [29]. In the current study, cysteine at low level decreased the release of malondialdhyde (TBARS) and increased the activity of SOD and GPX. This effect was attributed to the protective effect of cysteine on the sperm cellular level preventing the toxic oxygen species from causing lipid peroxidation [30]. Supplementing the freezing media of goat and ram semen by cysteine enhanced post-thaw motility [31]-[33] and improved membrane integrity of boar sperm [34]. Using high levels of cysteine did not protect goat sperm membrane and sperm viability during freezing [35]. Uysal and Bucak demonstrated that increasing doses of cysteine $(15 \mathrm{mM})$ decreased post-thaw sperm abnormality and increased acrosomal damage in rams [31]. The best sperm survival in the current tested cysteine levels was found at the lowest concentration $(1 \mathrm{mM})$. Above this level, there found a significant $(\mathrm{P}<0.01)$ decline in sperm survival accompanied with increased free radicals and decreased antioxidant enzyme activity. Recently, Kledmanee et al. showed that the protective effect of cysteine on carp chilled sperm was attained by using levels up to $1 \mathrm{mM}$ cysteine, however above this level there found deleterious effects on sperm characteristics [36]. This observation was also confirmed on post-thaw quality of Sahiwal bull semen [11].

Kubovicova et al. found that addition of glutathione (but not caffeine) has a positive effect on fertilizing ability of ram spermatozoa [37]. Moreover, the cycle of freezing and thawing has been reported to be responsible for a decrease in the level of antioxidants such as glutathione (GSH) or superoxide dismutase (SOD) in human and bovine spermatozoa [29] [38]. This decrease in antioxidants would enable ROS to cause sperm damage during the freezing process. The determinant role of superoxide dismutase (SOD) in the antioxidant defense systems has been known since 1968. It is well known that superoxide ion $\left(\mathrm{O}^{2-}\right)$ is the starting point in the chain production of free radicals. At this early stage, superoxide dismutase inactivates the superoxide ion by transforming it into hydrogen peroxide $\left(\mathrm{H}_{2} \mathrm{O}_{2}\right)$. The latter is then quickly catabolised by catalase and peroxidases into dioxygen $\left(\mathrm{O}_{2}\right)$ and water $\left(\mathrm{H}_{2} \mathrm{O}\right)$. Different studies have confirmed that the production of $\mathrm{H}_{2} \mathrm{O}_{2}$ under the action of SOD is the triggering factor in the natural antioxidant defense mechanisms. SOD therefore seems to be the key enzyme in the natural defense against free radicals [39]. In the current study, the significant increases of SOD and GPX activities coinciding with the high post-thaw sperm survival in the glutathione-supplemented ram semen were confirmed in the early finding by Michiels et al. [40]. The mechanism by which glutathione plays its role is attributed to that the enzyme glutathione peroxidase reduces lipidic or non-lipidic hydroperoxides and $\mathrm{H}_{2} \mathrm{O}_{2}$ during the oxidation of two molecules of glutathione. Since GSH serves as a hydrogen donor, the enzyme 
GPx functions linearly. As GSH concentration increases the reaction accelerates and the sperm cell protection improves [41].

\section{Conclusion}

For the best protection against the increased free radicals production during chilling preservation of ram semen, extenders must contain 1 - 2 mM glutathione or 5 IU Vitamin E per ml. The intensive production of free radicals in seminal plasma was counteracted by the inclusion of vitamin $\mathrm{E}$ or glutathione at the above mentioned concentrations. However, the supplementation of ram semen extender with cysteine hasn't showed the desirable protective effects. Further studies are required to test the impacts of inclusion of such antioxidants in the freezing media on subsequent sperm fertilization in vivo.

\section{Acknowledgements}

The authors acknowledge the funding of the project No. SR-D-012-1368 provided by Qassim University Scientific Research Deanship, without which this work wouldn't has been appeared.

\section{References}

[1] Sinha, M.P., Sinha, A.K., Singh, B.K. and Prasad, R.L. (1996) The Effect of Glutathione on the Motility, Enzyme Leakage and Fertility of Frozen Goat Semen. Theriogenology, 41, 237-243.

[2] Sanocka, D.M. and Kurpisz, M. (2004) Reactive Oxygen Species and Sperm Cells. Reproductive Biology and Endocrinology, 2, 12-18. http://dx.doi.org/10.1186/1477-7827-2-12

[3] Thuwanut, P., Chatdarong, K., Bergqvist, A.S., Söderquist, L., Thiangtum, K., Tongthainan, D. and Axnér, E. (2011) The Effects of Antioxidants on Semen Traits and in Vitro Fertilizing Ability of Sperm from Flat-Headed Cat (Prionailurus planiceps). Theriogenology, 76, 115-125. http://dx.doi.org/10.1016/j.theriogenology.2011.01.024

[4] Flora, S.J.S. (2009) Structural, Chemical and Biological Aspects of Antioxidants for Strategies against Metal and Metalloid Exposure. Oxidative Medicine and Cellular Longevity, 2, 191-206. http://dx.doi.org/10.4161/oxim.2.4.9112

[5] Maia, M.S., Bicudo, S.D., Azevedo, H.C., Sicherle, C.C., Sousa, D.B. and Rodello, L. (2009) Motility and Viability of Ram Sperm Cryopreserved in a Tris-Egg Yolk Extender Supplemented with Anti-Oxidants. Small Ruminant Research, 85, 85-90. http://dx.doi.org/10.1016/i.smallrumres.2009.07.001

[6] Maia, M.S., Bicudo, S.D., Sicherle, C.C., Rodello, L. and Gallego, I.C.S. (2010) Lipid Peroxidation and Generation of Hydrogen Peroxide in Frozen-Thawed Ram Semen Cryopreserved in Extenders with Anti-Oxidants. Animal Reproduction Science, 122, 118-123.

[7] Bilodeau, J.F., Blanchette, S., Gagnon, C. and Sirard, M.A. (2001) Thiols Prevent $\mathrm{H}_{2} \mathrm{O}_{2}$-Mediated Loss of Sperm Motility in Cryopreserved Bull Semen. Theriogenology, 56, 275-286. http://dx.doi.org/10.1016/S0093-691X(01)00562-3

[8] Ansari, M.S., Rakha, B.A., Ullah, N., Andrabi, S.M.H., Iqbal, S., Khalid, M. and Akhter, S. (2010) Effect of Exogenous Glutathione in Extender on the Freezability of Nili-Ravi Buffalo (Bubalus bubalis) Bull Spermatozoa. Animal Science Papers and Reports, 28, 235-244.

[9] Triwulanningsih, E., Situmorang, P., Sugiarti, T., Sianturi, R. and Kusumaningrum, D.A. (2008) The Effect of Glutathione in Sperm Diluents on the Quality of Bovine Chilled Semen. Indonesia Journal of Agriculture, 1, 64-69.

[10] Lenzi, A., Picardo, M., Gandini, L. and Dondero, F. (1996) Lipids of the Sperm Plasma Membrane: From Polyunsaturated Fatty Acids Considered as Markers of Sperm Function to Possible Scavenger Therapy. Human Reproduction Update, 2, 246-256. http://dx.doi.org/10.1093/humupd/2.3.246

[11] Ansari, M.S., Rakha, B.A. and Akhter, S. (2011) Effect of L-Cysteine in Extender on Post-Thaw Quality of Sahiwal Bull Semen. Animal Science Papers and Reports, 29, 197-203.

[12] Barbas, J.P. and Mascarenhas, R.D. (2009) Cryopreservation of Domestic Animal Sperm Cells. Cell and Tissue Banking, 10, 49-62. http://dx.doi.org/10.1007/s10561-008-9081-4

[13] Tateno, H., Kimura, Y. and Yanagimachi, R. (2000) Sonication Per Se Is Not as Deleterious to Sperm Chromosomes as Previously Inferred. Biology of Reproduction, 63, 341-346. http://dx.doi.org/10.1095/biolreprod63.1.341

[14] Marklund, S.L., Holme, E. and Hellner, L. (1982) Superoxide Dismutase in Extracellular Fluids. Clinica Chimica Acta, 126, 41-51. http://dx.doi.org/10.1016/0009-8981(82)90360-6

[15] Paglia, D.E. and Valentine, W.N. (1967) Studies on the Quantitative and Qualitative Characterization of Erythrocyte Glutathione Peroxidase. Journal of Laboratory and Clinical Medicine, 70, 158-169.

[16] Armstrong, D. and Browne, R. (1994) The Analysis of Free Radicals, Lipid Peroxides, Antioxidant Enzymes and 
Compounds Related to Oxidative Stress as Applied to the Clinical Chemistry Laboratory. Advances in Experimental Medicine and Biology, 366, 43-58. http://dx.doi.org/10.1007/978-1-4615-1833-4_4

[17] SAS (2000) User's Guide. Version 8, Statistical Analysis System, SAS Institute, Cary, NC.

[18] Steel, R.G.D. and Torrie, J.H. (1980) Principles and Procedures of Statistics. McGraw-Hill Book Company Inc., New York.

[19] Martin, G., Sabido, O., Durand, P. and Levy, R. (2004) Cryopreservation Induces an Apoptosis-Like Mechanism in Bull Sperm. Biology of Reproduction, 71, 28-37. http://dx.doi.org/10.1095/biolreprod.103.024281

[20] Guthrie, H.D. and Welch, G.R. (2006) Determination of Intracellular Reactive Oxygen Species and High Mitochondrial Membrane Potential in Viable Boar Sperm Using Fluorescence Activated Flow Cytometry. Journal of Animal Science, 84, 2089-2100. http://dx.doi.org/10.2527/jas.2005-766

[21] Salamon, S. and Maxwell, W.M.C. (1995) Frozen Storage of Ram Semen II. Causes of Low Fertility after Cervical Insemination and Methods of Improvement. Animal Reproduction Science, 38, 1-36. http://dx.doi.org/10.1016/0378-4320(94)01328-J

[22] Gillan, L., Evans, G. and Maxwell, W.M.C. (1997) Capacitation Status and Fertility of Fresh and Frozen-Thawed Ram Spermatozoa. Reproduction, Fertility and Development, 9, 481-488. http://dx.doi.org/10.1071/R96046

[23] Yousef, M.I., Abdallah, G.A. and Kamel, K.I. (2003) Effect of Ascorbic Acid and Vitamin E Supplementation on Semen Quality and Biochemical Parameters of Male Rabbits. Animal Reproduction Science, 76, 99-111. http://dx.doi.org/10.1016/S0378-4320(02)00226-9

[24] Sharma, R.K. and Agarwal, A. (1996) Role of Reactive Oxygen Species in Male Infertility. Urology, 48, 835-850. http://dx.doi.org/10.1016/S0090-4295(96)00313-5

[25] Bansal, A.K. and Bilaspurl, G. (2009) Antioxidant Effect of Vitamin E on Motility, Viability and Lipid Peroxidation of Cattle Spermatozoa under Oxidative Stress. Animal Science Papers and Reports, 27, 5-14.

[26] Anghel, A., Zamfirescu, S., Coprean, D. and Sogorescu, E. (2009) The Effects of Cysteine, Bovine Serum Albumin and Vitamin E on the Qualitative Parameters of Frozen-Thawed Ram Semen. Analele Societatii Nationale de Biologie Celulara, 14, 97-103.

[27] Michael, A., Alexopoulos, C., Pontiki, E., Hadjipavlou-Litina, D., Saratsis, P. and Boscos, C. (2007) Effect of Antioxidant Supplementation on Semen Quality and Reactive Oxygen Species of Frozen-Thawed Canine Spermatozoa. Theriogenology, 68, 204-212. http://dx.doi.org/10.1016/j.theriogenology.2007.04.053

[28] Andreea, A. and Stela, Z. (2010) Role of Antioxidant Additives in the Protection of the Cryopreserved Semen against Free Radicals. Romanian Biotechnological Letters, 15, 33-41.

[29] Bilodeau, J.F., Chatterjee, S., Sirard, M.A. and Gagnon, C. (2000) Levels of Antioxidant Defenses Are Decreased in Bovine Spermatozoa after a Cycle of Freezing and Thawing. Molecular Reproduction and Development, 55, 282-288. http://dx.doi.org/10.1002/(SICI)1098-2795(200003)55:3<282::AID-MRD6>3.0.CO;2-7

[30] Meister, A. and Tate, S.S. (1976) Glutathione and Related Gamma-Glutamyl Compounds: Biosynthesis and Utilization. Annual Review of Biochemistry, 45, 559-604. http://dx.doi.org/10.1146/annurev.bi.45.070176.003015

[31] Uysal, O. and Bucak, M.N. (2007) Effects of Oxidized Glutathione, Bovine Serum Albumin, Cysteine and Lycopene on the Quality of Frozen-Thawed Ram Semen. Acta Veterinaria Brno, 76, 383-390. http://dx.doi.org/10.2754/avb200776030383

[32] Ateşşahin, A., Bucak, M.N., Tuncer, P.B. and Kızıl, M. (2008) Effect of Antioxidant Additives on Microscopic and Oxidative Parameters of Angora Goat Semen Following the Freeze-Thawing Process. Small Ruminant Research, 77, 38-44. http://dx.doi.org/10.1016/j.smallrumres.2008.03.002

[33] Bucak, M.N. and Uysal, O. (2008) The Role of Antioxidants in Freezing of Saanen Goat Semen. Indian Veterinary Journal, 85, 148-150.

[34] Funahashi, H. and Sano, T. (2005) Select Antioxidants Improve the Function of Extended Boar Semen Stored at $10^{\circ} \mathrm{C}$. Theriogenology, 63, 1605-1616. http://dx.doi.org/10.1016/j.theriogenology.2004.06.016

[35] Kulaksiz, R. and Daskin, A. (2010) In Vitro Evaluation of Saanen Buck Semen Frozen in Different Extenders Supplemented with Various Antioxidants. Ankara Üniversitesi Veteriner Fakültesi Dergisi, 57, 151-156.

[36] Kledmanee, K., Taweedet, S., Thaijongruk, P., Chanapiwat, P. and Kamponkaeoket, K. (2013) Effect of L-Cysteine on Chilled Carp (Cyprinus carpio) Semen Qualities. Thai Journal of Veterinary Medicine, 43, 91-97.

[37] Kubovicova, E., Riha, L', Makarevich, A.V., Apolen, D. and Pivko, J. (2010) Effect of Different Semen Extenders and Additives to Insemination Doses on Ewes’ Pregnancy Rate. Slovak Journal of Animal Science, 43, 118-122.

[38] Alvarez, J.G. and Storey, B.T. (1992) Evidence for Increased Lipid Peroxidative Damage and Loss of Superoxide Dismutase Activity as a Mode of Sublethal Cryodamage to Human Sperm during Cryopreservation. Journal of An- 
drology, 13, 232-241.

[39] Menvielle-Bourg, F.J. (2005) Superoxide Dismutase (SOD), a Powerful Antioxidant, Is Now Available Orally. Phytothérapie, 3, 1-4.

[40] Michiels, C., Raes, M., Toussaint, O. and Remacle, J. (1994) Importance of SE-Glutathione Peroxidase, Catalase and $\mathrm{Cu} / \mathrm{Zn}$ SOD for Cell Survival against Oxidative Stress. Free Radical Biology and Medicine, 17, 235-248. http://dx.doi.org/10.1016/0891-5849(94)90079-5

[41] Flohe, L., Gunzler, W.A. and Schock, H.H. (1973) Glutathione Peroxidase: A Selenoenzyme. FEBS Letters, 32, 132134. http://dx.doi.org/10.1016/0014-5793(73)80755-0 
Scientific Research Publishing (SCIRP) is one of the largest Open Access journal publishers. It is currently publishing more than 200 open access, online, peer-reviewed journals covering a wide range of academic disciplines. SCIRP serves the worldwide academic communities and contributes to the progress and application of science with its publication.

Other selected journals from SCIRP are listed as below. Submit your manuscript to us via either submit@scirp.org or Online Submission Portal.
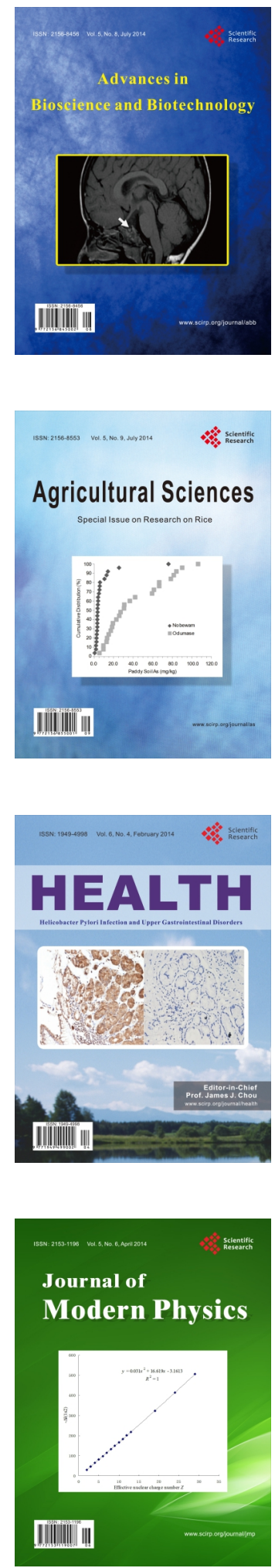
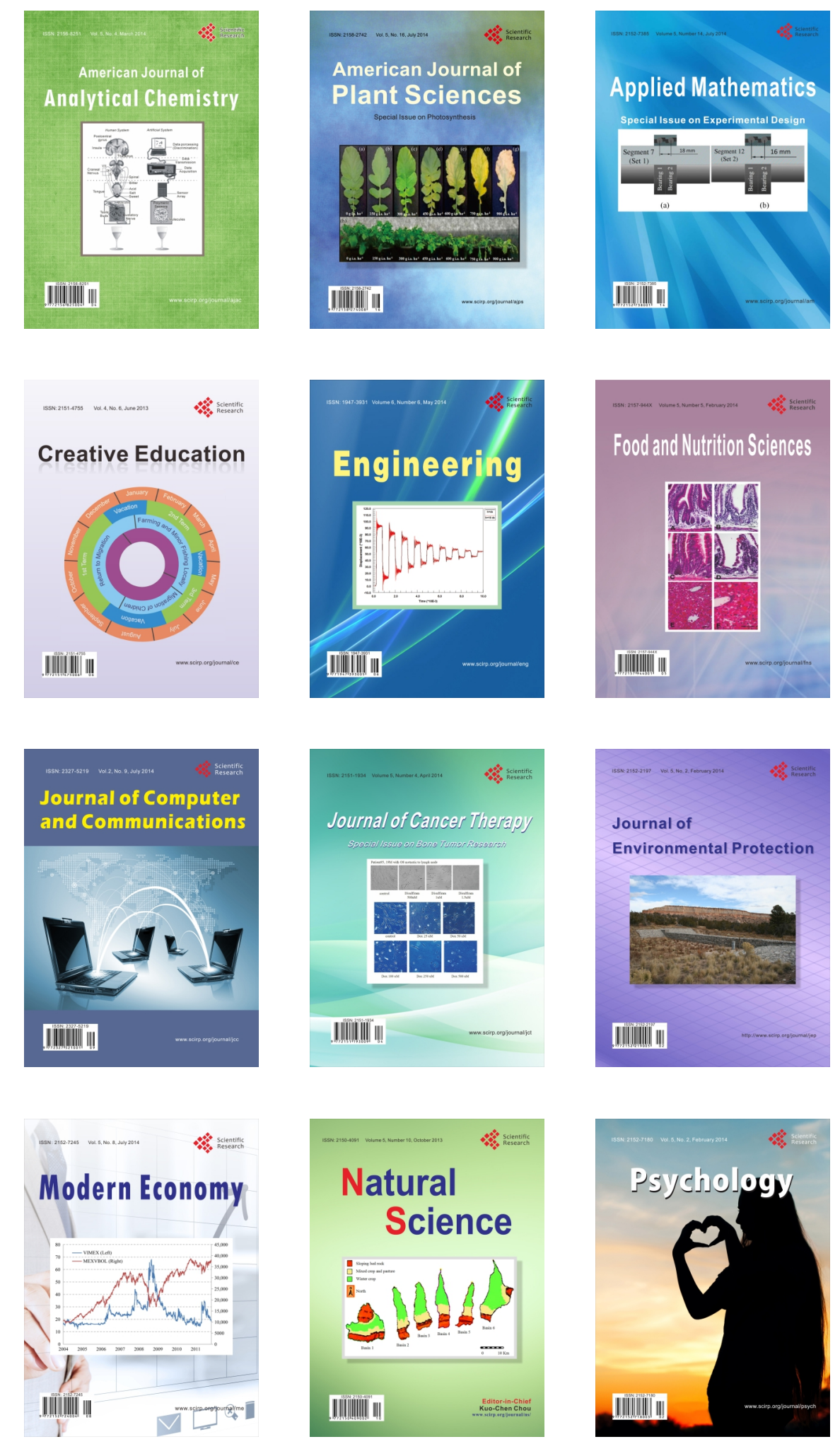